\title{
The Vulnerability Framework Integrates Various Models of Generating Surplus Revenue
}

Received (in revised form): April 8, 2004

\section{Vincent Maniaci}

Dr. Vincent Maniaci has been the Vice President for Institutional Advancement at Bellarmine University since 1997. He also teaches in Bellarmine's undergraduate core program and has an appointment to the University's Rubel School of Business where he teaches in the MBA program. This paper was adapted from his doctoral dissertation at the University of Pennsylvania GSE. He received the Grenzebach Award for Outstanding Dissertation in the field of Philanthropy for Education in 2003.

\section{Rob Poole}

Dr. Rob Poole graduated with a BS in Economics from Texas A\&M, where he was commissioned in the Marine Corps and was stationed all around the world. Returning to the USA, he went to USC for a master's degree in systems management. Later he obtained a Ph.D. in operations management and has taught at several schools, including the University of North Texas, Central Missouri State University, and Bellarmine University, where he led the MBA program. He researches and consults on a variety of interests including education reform, fund raising, and other applied process improvements.

\begin{abstract}
Budgets operationalize the strategic planning process, and institutions must have surplus revenue to be able to cope with future operations. There are three approaches to generate surplus revenue: increased revenue, decreased cost, and reallocation of resources. Extending their earlier work, where they established strategic benchmarks for annual funds and endowment payout, the authors demonstrate how each of the surplus revenue-generating approaches can be
\end{abstract}

Author's Contact Address:

Vincent M. Maniaci

Vice President for Institutional Advancement

Bellarmine University

2001 Newburg Road

Louisville, KY 40205, USA

Phone: +1 502 452-8328

Fax: +1 5024528337

Email: vmaniaci@bellarmine.edu combined into an integrated vulnerability model. This integrated vulnerability model provide a taxonomy for institutions to identify appropriate environments in which to emphasize one or more of the surplus generating approaches, which in turn should improve the institution's strategic planning process.

\section{Keywords:} annual fund, tuition dependency, strategic planning, operating budgets, vulnerability model, resource allocation, endowment payout

\section{Introduction}

Mission, strategic planning, and budgeting are critical to the well-being of institutions in higher education. Unfortunately, many institutions do not integrate them effectively. Strategic 
planning must start with the charter of the organization and address its internal and external environment. Effective planning requires expenditures to be prioritized and aligned with revenues according to mission and return on investment. The budget is the way to operationalize the strategic planning of the institution. Budgets must have surplus revenue to be able to cope with future operations.

According to Zemsky and Massy, there are only three models used for generating surplus revenue: increased revenue, decreased cost, and reallocation of resources. ${ }^{1}$ These are by no means mutually exclusive and all three models should be considered during the annual budget process with different emphasis depending on the needs of the institution. The purpose of this paper is to demonstrate a framework that integrates these three models so that trustees and administrators can identify the appropriate environment in which to emphasize one or more of the approaches.

The framework for this paper was developed through an earlier study by Maniaci, Poole, and Wilson, ${ }^{2}$ which investigated how present decisions related to budget and revenue allocation impact tuition dependency over a period of time. In the current study they examined the relationship between the level of annual fund raising for operations and endowment payout. Based on these relationships a taxonomy of institutions was developed that indicates which model of revenue generations should be used.

The Voluntary Support of Education report was used as a database to test 98 private master's- granting institutions in 1992 and 2001. ${ }^{3}$ The 10-year difference is deemed sufficient time for changes in programs to be noticed. Private schools were chosen to eliminate the effect of government subsidy, and doctoralgranting institutions were ruled out because of the additional cost of research in their budgets. Master's-granting schools have a wide range of programs and are more stable than baccalaureate-granting institutions.

\section{Increased Revenue}

Drucker says that growth in the private sector is not merely desirable, it is necessary. This is also true for universities, for one can only regress by attempting to maintain the status quo. ${ }^{4}$ This is to suggest that an institution that does not embrace change will certainly lose ground in the competitive environment of higher education. The Higher Education Price Index (HEPI) provides a guide to inflation in higher education. ${ }^{5}$ In Drucker's view, institutional revenue must increase annually beyond the HEPI rate of inflation or else the institution may risk losing ground to its competitors.

Emphasizing growth through surplus revenue is most effective when an institution is operating at maximum efficiency. Inefficient institutions may achieve growth without managing for surplus revenue by reallocating resources more efficiently in greater alignment with mission-driven priorities and with an eye toward return on investment. We will discuss reallocation of resources later in this paper.

Revenue at universities that grant master's degrees is derived from three primary sources: "students/parents pay tuition, the government subsidizes the cost of public schools, and philanthropists donate money to the annual fund or to endowment, some percentage of which is available for 
spending each year." "Thus covering one's costs becomes a zero sum game, in which a "lessening of the burden upon revenue from one source must be compensated either by a reduction of underlying costs or by a shift of the burden to another."7

Tuition has the advantage of being mission-driven. After all, the main purpose of the private universities that grant master's degrees is to educate its students, and there should be some relationship between the mission of an institution and its primary users. Yet tuition rates are a function of economic markets and there is a cap on how high tuition rates can be set without impacting the number and quality of the students that apply. At a certain point, increasing tuition can lead to lowering the amount of revenues received by the institution as fewer students enroll.

Private institutions have limited ability to raise money through government subsidy. This source is minimal for the great majority of private universities. Research grants may be the way to accomplish this for doctoral-granting institutions, but this option is constrained for universities that grant bachelor's and master's degrees.

An additional caution of relying on increased revenue as a means to generate a surplus was outlined by Maniaci, Poole, and Wilson where they established a benchmark suggesting that no more than 4 percent of the operational budget should be borne by the annual fund. ${ }^{8}$ Schools exceeding that benchmark became more dependent upon tuition as a source of revenue for their budgets.

\section{Decrease Cost}

Bowen disparages the need for additional revenue. In fact, increased revenue may be detrimental according to his "laws" of higher education:
1. The dominant goals of institutions are educational excellence, prestige, and influence.

2. In the quest for excellence, prestige, and influence, there is virtually no limit to the amount of money an institution could spend for seemingly fruitful educational ends.

3. Each institution raises all the money it can.

4. Each institution spends all it raises. ${ }^{9}$

Bowen goes on to say that the only way to curb the insatiable appetite for revenue in higher education is to limit the amount of money available to it. ${ }^{8}$ Regardless of what one might believe about the relative merit of Bowen's ideas about educational excellence, prestige, and influence and money, the costs for universities are relatively fixed. Rent, utilities, and debt are generally locked in year to year.

The major cost is for salaries. Faculty and staff can represent 90 percent of a budget as colleges and universities are labor-intensive. There is a compelling demand to maintain salaries at the rate of inflation and to accommodate employees with reasonable benefits despite the soaring cost of health care insurance.

Some schools minimize this fixed cost by hiring adjunct faculty in place of fulltime professors. They pay the part-timers a fraction of the full-time rate. Schools hire adjuncts for limited periods of time, generally no more than two or three years at a time with a maximum of five years, although in some cases community leaders and professional experts may teach for greater periods. These continuing adjuncts provide critical skill levels for areas unable to justify full-time positions. This practice also takes advantage of local talent which enhances institutional brand image and reinforces local pride. 
A typical master's-granting institution keeps only 70-80 percent of the teaching staff as full- time faculty, according to the US Neres and World Report in their annual evaluation of colleges for last year. ${ }^{11}$ This allows for surges in enrollment in particular majors in a particular year and drops in attendance the next year as the popularity of major fields of study wax and wane in the short term. If positive trends in the enrollment in particular majors become more pronounced, this becomes a justification for schools to "add a line" to the full-time number of faculty in a given discipline. This adds to the fixed costs of the institution from then on.

Regardless of what methods are applied to exercise cost control, this practice is limited by extent, duration, and effectiveness. Institutions may be able to reduce costs for nonessential items or find more economical ways of conducting business as usual for a period of time, but ultimately this practice alone as a means of achieving surplus revenue will result in a diminution of quality and services offered.

\section{Reallocation of Resources}

Schools must be willing to reengineer processes with an eye toward eliminating nonvalue-added processes. It is a rare institution that is excellent in all areas. A proper reevaluation of the mix of programs, offered consistent with the mission of the institution, should provide boards with areas to prune to free capital to invest in more promising areas. Applied routinely, this process can help to insure that the mission statement of an institution is effective. Indeed, review and revision of the mission through strategic planning must be an ongoing process of improvement. In turn, this requires a continuous reallocation of resources to operationalize the budget in alignment with the changing mission or vision of the institution.

\section{Lefrancois states:}

[I]n a university context of diminishing resources, the greatest risk is to stop growing, to survive by indiscriminately under-financing all fields of activity.

And it is false to believe that development necessarily implies additional resources or expansion. Growth does not necessarily mean more money. This can very well come about through the redistribution of resources, greater productivity, and the systematic search for quality and excellence. $^{12}$

A further issue that complicates institutional budgeting effectiveness is the planning time horizon. Hansmann questions why gift income or any form of income is accumulated in the form of endowment rather than being spent more or less currently. ${ }^{13}$ This position is supported by the argument that it is difficult to project the needs of the future and that current spending supports future investment because current assets will continue to appreciate.

Hansmann goes on to argue that "it would seem more equitable to have future generations subsidize the present. This could be accomplished by having universities borrow rather than save, and then repay the debt by increasing tuition in the future." ${ }^{14} \mathrm{He}$ does concede that one possible reason for allocating gift revenue to endowment is to have a reserve against financial reversals. In comparing temporary financial shocks in colleges and universities to those of business firms, he finds that higher education institutions are more vulnerable to temporary financial shocks 
than ordinary business firms due to the following factors:

1. Limited capability to borrow because organization specific assets make poor collateral.

2. Inability to sell equity.

3. Limited flexibility in adjusting scale of operations due to tenure. ${ }^{15}$

Massy describes the advantages and disadvantages of different time horizons as follows:

1. Judgments not only are subjective, but they involve indirect as well as direct effect, and they operate over disparate conceptual domains.

2. The investments can increase operating costs as well as produce benefits.

3. The investments can increase operating income, either directly or indirectly.

4. The benefits, costs, and income changes can be uncertain.

5. Endowment investments are reversible, investments in facilities are not.

6. The benefits, costs, and income changes can occur over long periods of time, and the time profiles can differ markedly from investment to investment. ${ }^{16}$

Massy suggests that generally, trustees have the lowest time discount rate of all institutional stakeholders. ${ }^{17}$ Presidents, given their short tenure relative to institutional history and the high pressure to balance day-to-day operations, are likely to have a very high subjective time discount. As the key decision maker, the president is often the overriding factor in determining to spend money currently as opposed to investing to mitigate future financial vulnerability or enhance future capability for growth. Needless to say, the amount of time discount one uses affects one's allocation of current resources.

\section{Integrated Model}

This study integrates the three models of generating surplus revenue into one generic framework based on relative amounts of annual fund raising and endowment payouts used in the operational budget. The integrated model shows when each of the earlier revenue models should be emphasized.

In their earlier study, Maniaci, Poole, and Wilson used analysis of variance which indicated an increase in tuition dependency for institutions found to be above the 4 percent benchmark for annual fund and a decrease in tuition dependency for institutions found to be above the 4 percent benchmark for endowment payout. ${ }^{18}$ They tested 97 private master's institutions in their study with results as shown in Figures 1 and 2.

These benchmarks are now presented in a taxonomy called the vulnerability model, whereby private master's-granting institutions are categorized by their degree of reliance on the annual fund and on the endowment payout to the operational budget. The reliance on annual fund for the operating budget is defined as high when the annual fund is above 4 percent of revenue used for operations and low when it is under 4 percent. Similarly, a high reliance on endowment payout is

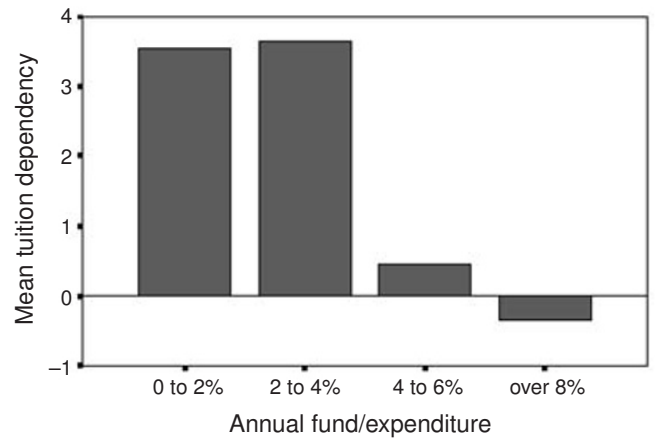

Figure 1: Tuition dependency as a function of annual fund to expenditure ratio 


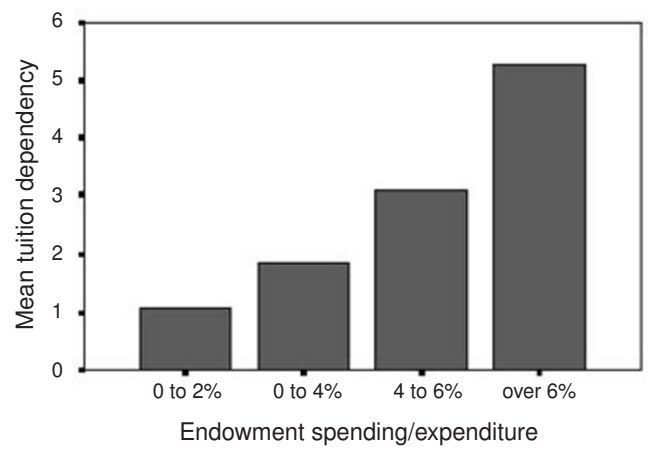

Figure 2: Tuition dependency as a function of endowment spending to expenditure ratio

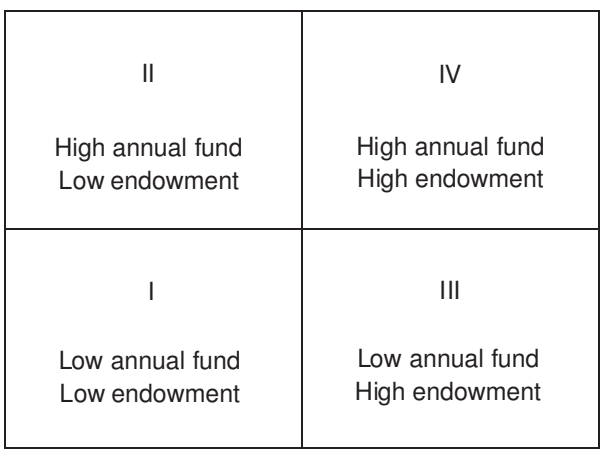

Figure 3: Vulnerability model

also established at 4 percent and low under 4 percent. The vulnerability model in Figure 3 is presented to demonstrate a context for emphasizing the different means of generating surplus revenue (increase revenue, decrease costs, or reallocation) based on institutional vulnerability.

\section{Category I}

Category I institutions are those schools with less than 4 percent of their operating budget paid for by annual fund raising and less than 4 percent of the budget paid by payout from endowments. These schools are vulnerable in the long run due to their high tuition dependency, but they are not necessarily unstable at the current time. There is no immediate problem with tuition dependency as long as there is ample student demand. However, should student demand decline, the financial vulnerability of these institutions becomes critical. Unless they plan ahead they may not have the proper mix of faculty and majors to attract the students of the future. Their current position is noted by a match of mission to expenditure. Although their educational excellence, prestige, and influence are limited, there is a market for such institutions.

Category I institutions can improve their lot for the future by emphasizing an increase in revenue, ideally through fund raising. If they are able to maintain current spending levels while generating more fund-raising revenue and place the money they raise in their endowment for future use they may eventually shift into much more stable and less vulnerable category III.

\section{Category II}

Category II institutions are those schools with more than 4 percent of their operating budget paid by annual fund raising, but less than 4 percent of the budget paid by payout from the endowment. These schools are in the least stable position currently. They have less flexibility than category I schools because they are already raising a high level of money for annual operations. Given the high priority placed on annual giving, it is more than likely that they are close to raising their full potential in the annual fund. Therefore, the option of increasing tuition revenue, which would increase their current dependency, or generating more endowment, which is difficult given the current level of their annual fund, is problematic.

It is important to note that annual 
giving and raising money from endowment are not mutually exclusive. However, budget support from endowment is a long-term proposition because only the payout (generally in the 5 percent range) is available for budget relief. For example, an institution with a \$20 million dollar operating budget would need to raise $\$ 20$ million dollars of endowment in one year in order to generate only 5 percent more revenue for operations.

Category II institutions can improve their lot for the future by continuing to raise money for the annual fund, but they must wean themselves from spending it now, instead allocating it for future operating budgets. These schools should attempt to reduce or maintain their operating costs to create a surplus in annual unrestricted fund raising into the endowment. These schools need to become more efficient at what they do, by changing their internal processes and strategic mix of operations. In short, Category II institutions should reallocate their resources, which over time will help to shift these instructions into category III.

\section{Category III}

Category III institutions are those schools with less than 4 percent of their operating budget paid for by annual fund raising and more than 4 percent of the budget generated from payout of their endowments. These schools are futureoriented and revenues sources are well aligned with their mission. They are strategically stable both today and for the future. These schools have a strong strategic planning and budgeting orientation. Their educational excellence, prestige, and influence are high and deserved. While every institution benefits from surplus revenue, category III institutions most likely are generating surplus revenue with their current operations. They have the luxury of being able to pick and choose whichever method of generating even more surplus most comfortably fits their plan without an overarching need to emphasize any one particular method due to their financial predicament.

\section{Category IV}

Category IV institutions are those schools with more than 4 percent of their operating funds paid for by annual fund raising, and more than 4 percent of the budget paid by payout from the endowment. These schools are futureoriented, but have so much money that they can get strategically sloppy. They have the resources to take chances and sometimes they succeed and sometimes not. These schools are not restrained by their tuition and thus their mission can stray from their market.

Category IV schools can improve their lot by reducing costs, yet as with category III institutions, they are not necessarily immediately compelled to do so as they have the longest time horizon of all the schools. They have the highest amount of fixed costs, noted by the highest use of full-time faculty. Their educational excellence, prestige, and influence are high. Over time, they may allow their costs to get out of line and may shift into category II. Reducing those areas in which

\begin{tabular}{|c|c|}
\hline $\begin{array}{c}\text { II } \\
\text { Unstable today, emphasize } \\
\text { reallocating resources today } \\
\text { for future operations }\end{array}$ & $\begin{array}{c}\text { IV } \\
\text { Unstable today, } \\
\text { emphasize decreasing } \\
\text { future costs }\end{array}$ \\
\hline $\begin{array}{c}\text { Stable today, } \\
\text { emphasize increasing } \\
\text { future revenue }\end{array}$ & $\begin{array}{c}\text { III } \\
\text { Stable today, } \\
\text { emphasize current } \\
\text { and future strategy }\end{array}$ \\
\hline
\end{tabular}

Figure 4: Integrated model 
they have strayed from success will align their mission to the market and shift the school into category III.

\section{Conclusion}

The authors provide a framework to integrate the three ways that Zemsky and Massy (1995) describe to generate surplus revenue. Zemsky and Massy say that surplus revenue can be obtained by increasing revenue, decreasing costs, or reallocating resources. ${ }^{19}$ These methods are not mutually exclusive and having a framework would help trustees and administrators determine which method to emphasize.

By determining what percentage of the operating budget is paid for by the annual fund and the payout from endowment and thus categorizing their budgetary environment in the vulnerability framework, institutions will be better served in their strategic planning both in conducting a situational analysis and aligning their operating budget with their mission and vision. This framework defines four quadrants in a taxonomy of strategic budgetary environments based on vulnerability. The taxonomy will assist trustees and administrators in determining where their institutions fall in the vulnerability quadrant and thereby allow them to develop an appropriate plan to improve their position through a strategic planning process.

\section{References}

1. R. Zemsky and W. F. Massy (1995), "Expanding perimeters, melting cores and sticky functions: toward an understanding of our current predicaments," Change, 27, pp. 41-9.

2. V. M. Maniaci, R. R. Poole, and T. L. Wilson (2003), "The relationship of annual giving and endowment payout to future tuition dependency," CASE International Journal of Educational Advancement, 4, 2, pp. 115-26.

3. Council for Aid to Education (1988), 1988 Voluntary Support of Education, Council for Aid to Education, New York.

4. P. F. Drucker (1990), Managing the Non-Profit Organization: Practices and Principles, Harper Collins, New York.

5. Research Associates of Washington (2000), Higher Education Price Index, Research Associates of Washington, Arlington, VA.

6. D. B. Johnstone (1999), Financing Higher Education: Who Should Pay, Johns Hopkins University Press, Baltimore, p. 358.

7. Ibid.

8. Maniaci et al., "The relationship of annual giving and endowment payout to future tuition dependency at private master's universities," op. cit., p. 118.

9. H. R. Bowen (1980), The Costs of Higher Education: How Much Do Colleges and Universities Spend for Students and How Much Should They Spend? Jossey Bass, San Francisco.

10. Ibid.

11. US Newes and World Report (2003), America's Best Colleges.

12. R. A. Lefrancois (1984), "Challenge for the 1980s: productivity-oriented university management," Cost and Management, 58, 1, pp. 55-9 (quote p. 58).

13. H. Hansmann (1990), "Why do universities have endowment?" Journal of Legal Studies, 19, 1, pp. 3-34.

14. Ibid, p. 21.

15. Ibid

16. W. F. Massy (1990), Endowment: Perspectives, Policy, and Management, Association of Governing Boards of Universities and Colleges, Washington, DC.

17. Ibid.

18. Maniaci et al., "The relationship of annual giving and endowment payout to future tuition dependency," op. cit.

19. Zemsky and Massy, "Expanding perimeters, melting cores and sticky functions," op. cit.

\section{Practitioner's Perspective}

By publishing Dr. Maniaci and Dr. Poole's article, the International Journal of Educational Advancement has expanded its reach beyond advancement professionals. Their article is an important read for chief advancement, financial, and academic administrators throughout the country. It is relevant to chief executive advancement 
officers who participate in the overall financial planning of their institutions, and it clearly demonstrates that decisions about fund-raising programs and goals need to be made in the context of the institution's overall financial plan. It is especially useful for college and university presidents. Maniaci and Poole's extensive research demonstrates the importance of an institution's financial viability. It offers a helpful discussion of financial strategies employed by different types of institutions, based on the strength of their endowment and annual giving.

Maniaci and Poole point out that institutional mission and strategic planning are vital to financial health. As a college president, I can attest to the importance of Maniaci and Poole's assertion that financial viability must be viewed by both internal and external publics as an institution builds a base of support to fulfill and carry out its mission. They point out that surplus revenue over costs can be used to meet additional mission-related needs.

Maniaci and Poole's article addresses the importance of (1) increased revenue, (2) decreased cost, and (3) reallocation of resources to institutional viability. They discuss such issues as growth in enrollment versus growth in endowment, cost versus price, and the growing need for unrestricted revenue. They point out that fixed costs are increasing faster than inflation, that faculty concerns usually center on the quality of teaching, and that most institutions have never met a program they don't like. All this points back to the fact that financial viability often relates to how the faculty and administration, as well as the institution's governing board, understand and stay focused on institutional mission.

Maniaci and Poole incorporate other research along with their own in creating a vulnerability model based on strength of endowment and annual giving in four institutional categories. As one might guess, the model illustrates that institutions with small endowments and relatively modest unrestricted giving are severely limited in what they can accomplish, compared to institutions with large endowments and significant annual giving programs, which are strategically stable and usually futureoriented. Maniaci and Poole's model also includes institutions with large annual unrestricted giving programs but small endowments and those with large endowments but modest annual giving programs.

I found Dr. Maniaci and Dr. Poole's article helpful in looking at the institution I serve, and I will be sharing it with our governing board and other key constituents. From my view as a former chair of the CASE Board of Trustees and as a CASE member since its inception in 1974, I think Dr. Maniaci and Dr. Poole have given not only advancement professionals, but also key institutional leaders and constituents, a new way to look at the financial health of their institutions. 